Article

\title{
Synthesis and Structure-Activity Relationship of Daphnetin Derivatives as Potent Antioxidant Agents
}

\author{
Yangliu Xia ${ }^{1,+}$, Chen Chen ${ }^{2,+}$, Yong Liu ${ }^{1}$, Guangbo Ge ${ }^{3}$, Tongyi Dou ${ }^{1, *}$ and Ping Wang ${ }^{3, *}$ \\ 1 School of Life Science and Medicine, Dalian University of Technology, Panjin 124221, China; \\ xiayl@dlut.edu.cn (Y.X.); yliu@dlut.edu.cn (Y.L.) \\ 2 College of Life Science, Dalian Minzu University, Dalian 116600, China; chenchen@dlnu.edu.cn \\ 3 Institute of Interdisciplinary Medicine, Shanghai University of Traditional Chinese Medicine, \\ Shanghai 201203, China; gegbdicp@sohu.com \\ * Correspondence: douty@dicp.ac.cn (T.D.); s200541025@126.com (P.W.); \\ Tel.: +86-427-263-1425 (T.D.); +86-21-513-23184 (P.W.) \\ + These authors contributed equally to this work.
}

Received: 12 September 2018; Accepted: 26 September 2018; Published: 27 September 2018

check for updates

\begin{abstract}
In this study, daphnetin 1 was chosen as the lead compound, and C-3 or C-4-substituted daphnetins were designed and synthesized to explore the potential relationship between the antioxidant activities and the chemical structures of daphnetin derivatives. The antioxidant activities of the generated compounds were evaluated utilizing the free radical scavenging effect on 2,2'-diphenyl-1-picrylhydrazyl, 2,2'-azinobis-(3-ethylbenzthiazoline-6-sulfonate) cation, and the ferric reducing power assays, and were then compared with those of the standard antioxidant Trolox. The results showed that the catechol group was the key pharmacophore for the antioxidant activity of the daphnetins. The introduction of an electron-withdrawing hydrophilic group at the C-4 position of daphnetin enhanced the antioxidative capacity, but this trend was not observed for C-3 substitution. In addition, introduction of a a hydrophobic phenyl group exerted negative effects on the antioxidant activity in both the C-3 and C-4 substitutions. Among all of the derivatives tested, the most powerful antioxidant was 4-carboxymethyl daphnetin (compound 9), for which the strongest antioxidant activity was observed in all of the assays. In addition, compound 9 also displayed strong pharmaceutical properties in the form of metabolic stability. To summarize, compound 9 holds great potential to be developed as an antioxidant agent with excellent antioxidant activity and proper pharmacokinetic behavior.
\end{abstract}

Keywords: daphnetin; antioxidant activity; radical scavenging effect; structure-activity relationship

\section{Introduction}

Aerobic organisms form reactive oxygen species (ROS) as an unavoidable consequence of cell metabolism. In a healthy individual, there is an equilibrium between the natural antioxidative defense system and ROS. When the equilibrium is disrupted, ROS can induce both cellular damage responsible for aging and various pathologies in humans, such as rheumatoid arthritis, diabetes, and cancer [1-3]. A variety of powerful natural antioxidants have been identified that act as chemopreventive agents, which could prevent cancer through the action of antioxidants [4]. These compounds could also exert anti-mutagenicity, anti-carcinogenicity, and anti-aging properties, which are thought to originate from their antioxidant activities [5].

Natural compounds isolated from dietary or medicinal plants, which serve as rich sources of antioxidant agents, have been of increasing interest in recent decades. With the goal of searching for antioxidant components, the structure-activity relationships of some natural compounds have been 
extensively studied, generally focusing on the flavonoids and phenolic acids [6-8]. These reports demonstrated that the free radical scavenging and antioxidant activity of these compounds primarily depends on the type and position of the substituents on the aromatic ring of the molecules.

Coumarins are widely distributed in food and Chinese medicinal herbs, which are considered to be good natural sources of antioxidants. With excellent safety, high solubility, and good permeability, this family has received widespread attention [9-13]. As a representative coumarin, daphnetin (7,8-dihydroxycoumarin) has been approved as an adjunctive therapy for cardiovascular diseases in China since the 1980s, as well as receiving recognition as the marker compound for the quality control of the Zushima tablet, which has been used as a traditional Chinese medicine preparation to treat rheumatoid arthritis [14]. Daphnetin 1 and 4-methyl daphnetin $\mathbf{2}$ exhibited stronger activities in protecting mononuclear cells of umbilical blood from oxidative attack than resveratrol [15], and 4-methyl daphnetin 2 was found more effective in protection of human single cell DNA from oxidative attack than curcumin and resveratrol [16]. Although daphnetin $\mathbf{1}$ and its analogues (Figure 1) have been recognized to be good antioxidants, limited information is available on the structure-antioxidant activity relationship of daphnetin derivatives, which may provide vital information for the development of antioxidative agents based on daphnetin for the treatment or adjuvant treatment of oxidative stress-related diseases.

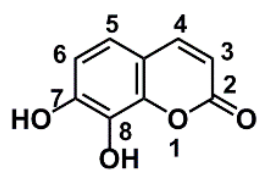

1

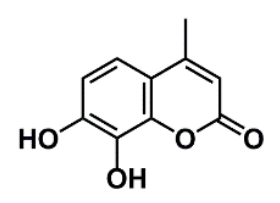

2

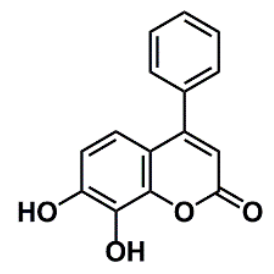

3

Figure 1. The structure of daphnetin and its analogues.

Therefore, daphnetin $\mathbf{1}$ was utilized in this study as a lead compound, and different groups with varied properties were introduced to the 3- or 4-position of daphnetin. The antioxidant activities of the derivatives were evaluated by examining their free radical scavenging effect using the FRAP, $\mathrm{DPPH}$, and $\mathrm{ABTS}^{+}$assays, and the potential structure-antioxidant activity relationships of daphnetins were discussed. In addition, the pharmaceutical activities of daphnetin derivatives, especially metabolic stability, which is the largest obstacle for the development of catechol coumarins as drugs, were investigated. In addition, we proposed a strategy of the simultaneous optimization of metabolic stability and pharmacological activity for these types of compounds. These findings could provide useful guidance to design and optimize potent antioxidants and the structural modifications of coumarin derivatives.

\section{Results and Discussion}

\subsection{Chemistry}

To explore the effects of different property groups and their position on daphnetin on its antioxidant activities, a series of 3- or 4-substituted daphnetin derivatives were designed. The substituents were selected mainly based on the electronic and lipophilic considerations defined by Craig's plot [17]. In the present study, trifluoromethyl, phenyl and carboxylic ester were selected for their electron-withdrawing and hydrophobic property; carboxymethyl and carboxyl were selected to represent electron-withdrawing and hydrophilic substituents, while groups like tert-butyl and methyl represented electron-donating and hydrophobic substituents; hydroxymethyl, azidomethyl, and chloromethyl were representative of electron-donating and hydrophilic substitution. The derivatives of daphnetin were prepared via Knoevenagel condensation and acid catalyzed Pechmann reaction. First, the introduction of different property groups at the C-4 position of daphnetin is shown 
in Scheme 1. The compounds 2-6 were synthesized via acid catalytic Pechmann condensation. 1,2,3-Phenenyl triacetate was reacted with the correctly substituted $\beta$-ketoester under perchloric acid catalysis to produce compounds $\mathbf{2}-\mathbf{6}$. Subsequently, compound 7 and compound $\mathbf{8}$ were obtained from chloride 6 by refluxing in a mixture of dimethylformamide (DMF) and water (3:10, v:v) and treating with sodium azide, respectively. 4-Carboxylic daphnetin $\mathbf{9}$ and its ester $\mathbf{1 0}$ were obtained by treating 1,2,3-phenenyl triacetate with 1,3-acetonedicarboxylic acid and dimethyl 1,3-acetonedicarboxylate, respectively, in the present of perchloric acid.

Ultimately a series of different property groups, including phenyl, cyano, carbonyl, carboxyl, carboxylic ester and benzothiazole, were introduced to the C-3 site of daphnetin. All these compounds were prepared from 2,3,4-trihydroxybenzaldehyde through Knoevenagel condensation (Scheme 2) [18]. The detailed experimental procedures are described in the Supporting Information. In addition, a cyano group was introduced in the position of daphnetin 19 by an addition/elimination reaction similar to that described in reference [19] with a brief modification. Subsequently, a cyano group of $\mathbf{2 0}$ was hydrolyzed to acid $\mathbf{2 1}$ and amide 22, as well as being converted to tetrazol $\mathbf{2 3}$ via the zinc-catalyzed [3 +2 ] cycloadditon reaction (Scheme 3). Compounds 21-23 were purified using preparative high-performance liquid chromatography.
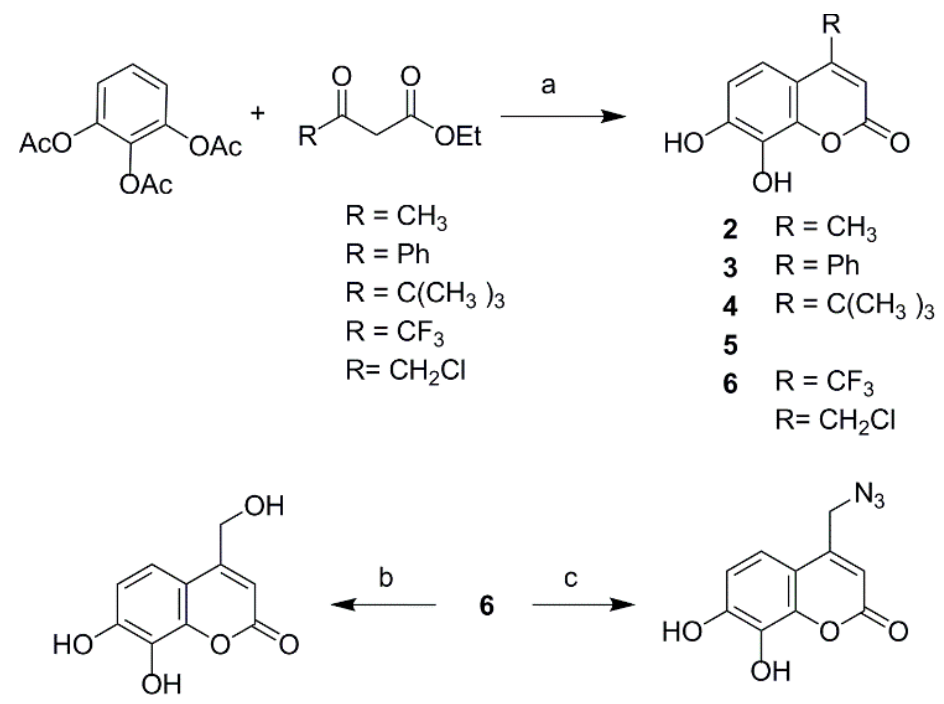

7

8

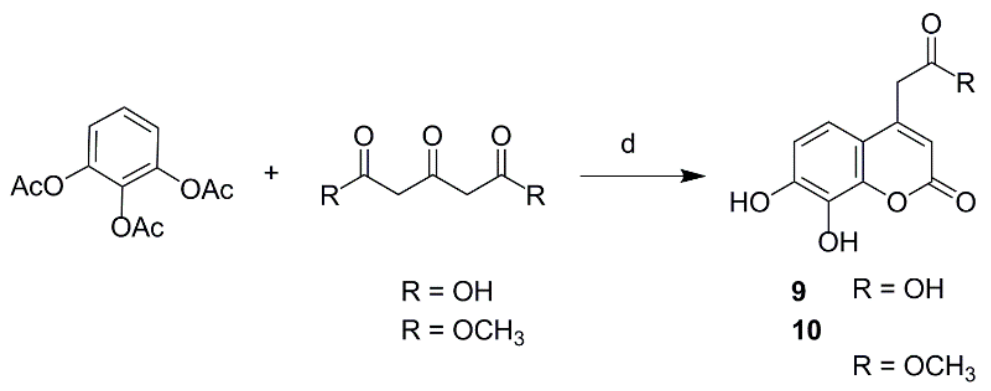

Scheme 1. Synthesis of 4-substituted daphnetin derivatives. Reagents and conditions: (a) $\mathrm{HClO}_{4}$, 25-60 ${ }^{\circ} \mathrm{C}, 6-8 \mathrm{~h}$; (b) DMF $/ \mathrm{H}_{2} \mathrm{O}$ (1:3), reflux, 20 h; (c) DMF, NaN 3 , rt, $10 \mathrm{~h}$; (d) $\mathrm{HClO}_{4}, 50{ }^{\circ} \mathrm{C}, 4 \mathrm{~h}$. 


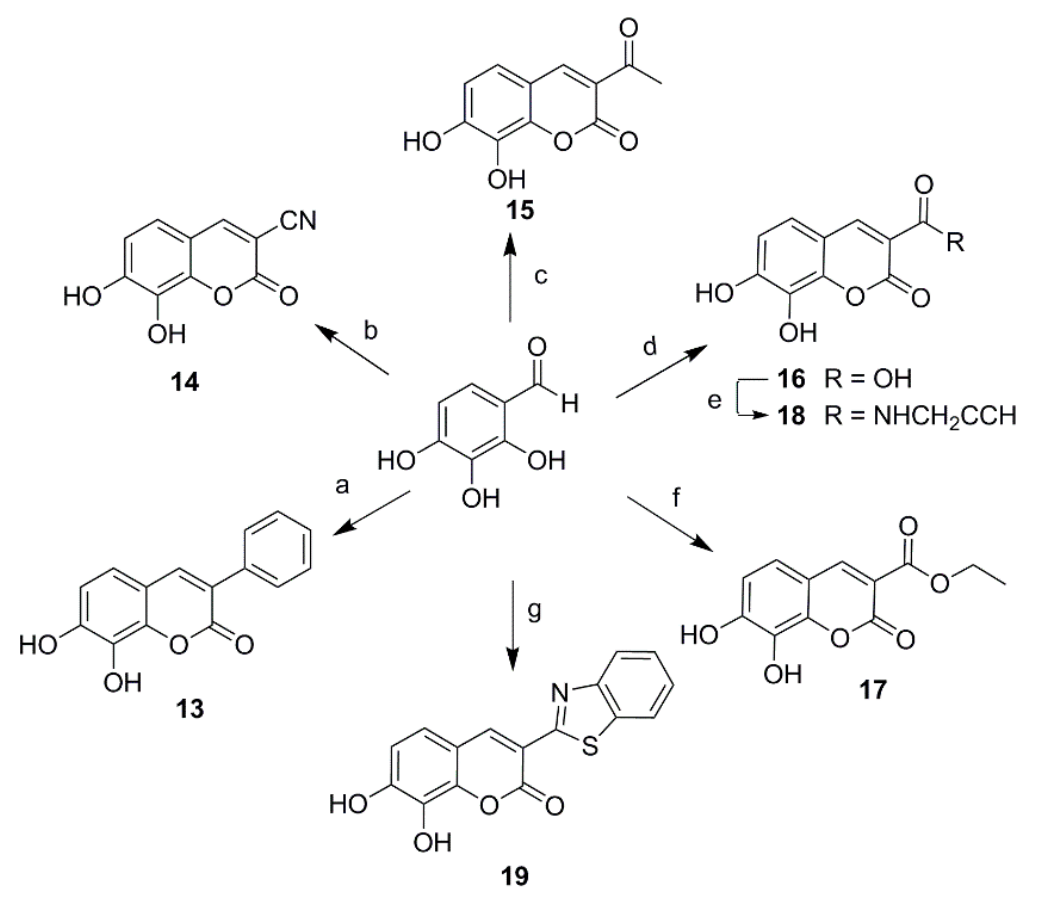

Scheme 2. Synthesis of 3-substituted daphnetin derivatives. Reagents and conditions: (a) phenylacetic acid, $\mathrm{AcONa}, \mathrm{Ac}_{2} \mathrm{O}, 6 \mathrm{~h}, 160{ }^{\circ} \mathrm{C}, 58 \%$; (b) malononitrile, $\mathrm{CH}_{3} \mathrm{COONH}_{4}, \mathrm{H}_{2} \mathrm{O}, \mathrm{rt}, 3 \mathrm{~h} ; \mathrm{HCl}(2 \mathrm{~mol} / \mathrm{L})$, $75{ }^{\circ} \mathrm{C}, 1 \mathrm{~h}, 80 \%$; (c) ethyl acetoacetate, piperidine, $\mathrm{MeOH}$, reflux, $3 \mathrm{~h}, 85 \%$; (d) Meldrum's acid, $\mathrm{CH}_{3} \mathrm{COONH}_{4}, \mathrm{H}_{2} \mathrm{O}$, rt, $4 \mathrm{~h}, 83 \%$; (e) 2-propynylamine, 1-hydroxybenzotriazole, EDCI, DMF, $5{ }^{\circ} \mathrm{C}$, $5 \mathrm{~h}, 74 \%$; (f) diethyl malonate, $\mathrm{CH}_{3} \mathrm{COONH}_{4}, \mathrm{H}_{2} \mathrm{O}, 50{ }^{\circ} \mathrm{C}, 5 \mathrm{~h}, 76 \%$; (g) ethyl 2-(benzo[d]thiazol-2-yl) acetate, piperidine, $\mathrm{MeOH}, 40{ }^{\circ} \mathrm{C}, 5 \mathrm{~h}, 88 \%$.

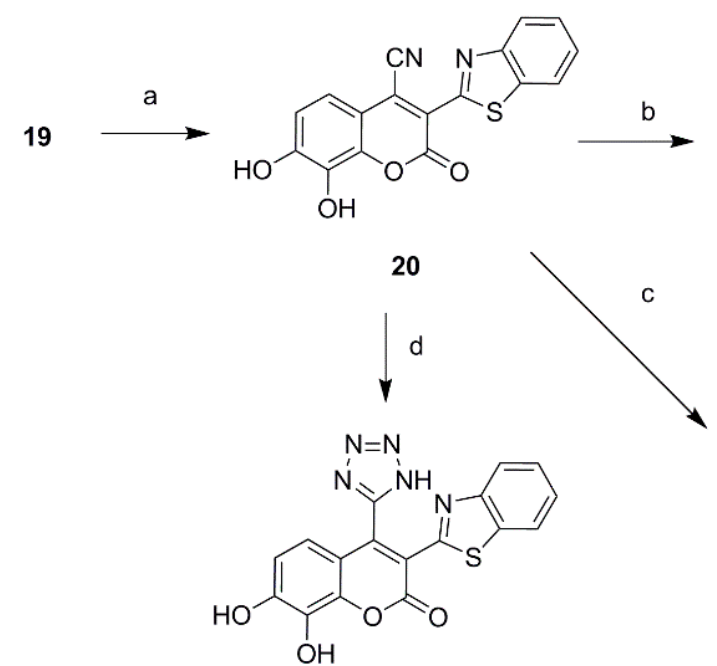

23<smiles>O=C(O)c1c(-c2nc3ccccc3s2)c(=O)oc2c(O)c(O)ccc12</smiles>

21<smiles>NC(=O)c1c(-c2nc3ccccc3s2)c(=O)oc2c(O)c(O)ccc12</smiles>

22

Scheme 3. Synthesis of 3-benzothiazole daphnetin derivatives. Reagents and conditions: (a) $\mathrm{NaCN}$, DMF, $\mathrm{I}_{2}, 6 \mathrm{~h}, 58 \%$; (b) $\mathrm{H}_{2} \mathrm{SO}_{4}, \mathrm{H}_{2} \mathrm{O}, 80{ }^{\circ} \mathrm{C}, 3 \mathrm{~h}, 36 \%$. (c) $\mathrm{H}_{2} \mathrm{SO}_{4}, \mathrm{H}_{2} \mathrm{O}, 100{ }^{\circ} \mathrm{C}, 8 \mathrm{~h} ; 60 \%$; (d) $\mathrm{ZnBr}, \mathrm{NaN}_{3}$, dioxane, $90{ }^{\circ} \mathrm{C}, 12 \mathrm{~h}, 42 \%$.

\subsection{Antioxidant Activity Assay In Vitro}

The antioxidant activity is influenced by many factors, which cannot be fully described with a single antioxidant assay. Thus, in this study, antioxidant activities in vitro were evaluated using the free radical scavenging effect on 2,2'-diphenyl-1-picrylhydrazyl (DPPH), 2,2'-azinobis(3-ethylbenzthiazoline-6-sulfonate) cation $\left(\mathrm{ABTS}^{+}\right)$. and the ferric reducing power (FRAP) assay, respectively, according to the literature with a slight modification [20-24]. The Trolox (6-hydroxy-2,5,7, 
8-tetramethylchroman-2-carboxylic acid; Sigma Aldrich, (St. Louis, MO, USA) standard solution (concentration range: $0-0.4 \mathrm{mmol} / \mathrm{L}$ ) was analyzed under the same conditions as those used for the calibration. First, the reducing power of these compounds was evaluated using the FRAP assay by measuring the ability of an antioxidant to reduce ferric (III) ions to ferrous (II) ions. The results of the total equivalent antioxidant capacity (TEAC) were expressed as the Trolox equivalent, i.e., mmol equivalents of Trolox per mmol of sample (mmol Trolox/mmol sample).

As shown in Figure 2, all the daphnetin derivatives tested exhibited better reducing power

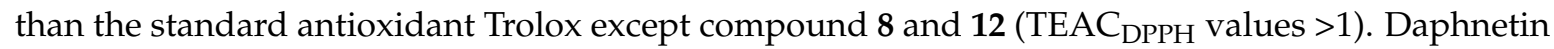
(DAP, 1) exhibited a 2.5-fold higher reducing antioxidant power than that of the standard antioxidant Trolox. A three-fold increase in reducing antioxidant power was observed when trifluoromethyl 5 or carboxyl group 9 was introduced to the C-4 position of daphnetin, while other C-4 substituents, including phenyl 3, methyl 2, tert-butyl 4, chloromethyl 6, hydroxymethyl 7 and azidomethyl 8, led to decreased activities of daphnetin but were still superior to Trolox except for the substitution of the azidomethyl group. The markedly decreased antioxidant activity of compound $\mathbf{8}$ is probably due to the ability of the azide group to cause the consumption of reducing agents and ultimately led to a lower reducing antioxidant power in comparison to the other substituents. In addition, the introduction of cyano 14 or acetyl group 15 improves the antioxidant activity of daphnetin, resulting in 3-fold higher antioxidant activity than that of Trolox. The C-3 carboxy substituent $\mathbf{1 6}$ of daphnetin displayed little effect on its antioxidant activity, and this situation did not change when the carboxyl group was esterified 17 or amidated 18, which is quite different from the significant decrease in antioxidant activity observed when converting the C-4 carboxy to its ester 10. In addition, after the introduction of a strong electron-withdrawing benzothiazole to the C-3 position, benzothiazole 19 exhibited a slightly reduced antioxidant activity. A simultaneous substitution at the C-4 position by carboxy group 21 led to a significant decrease in antioxidant activity, while this decline in activity could be alleviated by conversion of the carboxy group to amide 22 or its isostere tetrazolium 23 . However, it still had lower antioxidant activity compared with that of compound 19. It is notable that the blocking of two hydroxyls by an acetyl group led to a complete loss of total reducing power, indicating that catechol moieties are key groups for the antioxidant activity of the daphnetin derivatives.

To evaluate the antioxidant activity of daphnetin derivatives in detail, the $\mathrm{EC}_{50}$ values of these compounds were determined using the DPPH and $\mathrm{ABTS}^{+}$assays as shown in Table 1. In the DPPH assay, the $\mathrm{EC}_{50}$ value of DAP 1 is $46.20 \mu \mathrm{M}$, which is lower than that of Trolox $\left(\mathrm{EC}_{50}=53.16 \mu \mathrm{M}\right)$. Among these daphnetin derivatives, compound 4-carboxymethyl DAP 9 showed the strongest DPPH radical scavenging activity with $\mathrm{EC}_{50}$ values of $31.38 \mu \mathrm{M}$ (Figure 3 ). Similar to the results of the FRAP assay, a significant increase in the DPPH radical scavenging activities of the daphnetins could be obtained when the C-4 position was substituted by strong electron-withdrawing groups, such as an acetate group, while few changes in the $\mathrm{EC}_{50}$ value were observed when the trifluoromethyl group was introduced to the C-4 position of daphnetin. Positive effects of the carboxyl group to the antioxidant activity of daphnetin also appeared when the substitution site was located in the C-3 position, which could be weakened by esterification or amidation of the carboxyl group with $\mathrm{EC}_{50}$ values of $37.67 \mu \mathrm{M}, 43.98 \mu \mathrm{M}$, and $55.65 \mu \mathrm{M}$ for compound 16, 17, and 18, respectively. Interestingly, negative effects of cyano and acetyl on the DPPH radical scavenging activity of daphnetins appeared when the substitution site was switched from the C-4 to C-3 position, with the exception of an ethyl carboxylate group, in which a weakly enhanced activity was observed. In contrast to the same increased trend on the antioxidant activity of daphnetins when substituted by hydrophilic carboxyl, regardless of the C-3 or C-4 substitution, the substitution of hydrophobic phenyl exerted opposite effects towards the antioxidant activity of daphnetins depending on the substitution site. The antioxidant activity of 4-phenyl DAP 3 was lower than that of DAP 1, while 3-phenyl DAP 13 was more effective. In addition, the DPPH radical scavenging activity of daphnetin dramatically decreased towards the blocked catechol groups, illustrating the important role of the catechol moieties in the depletion of DPPH. 


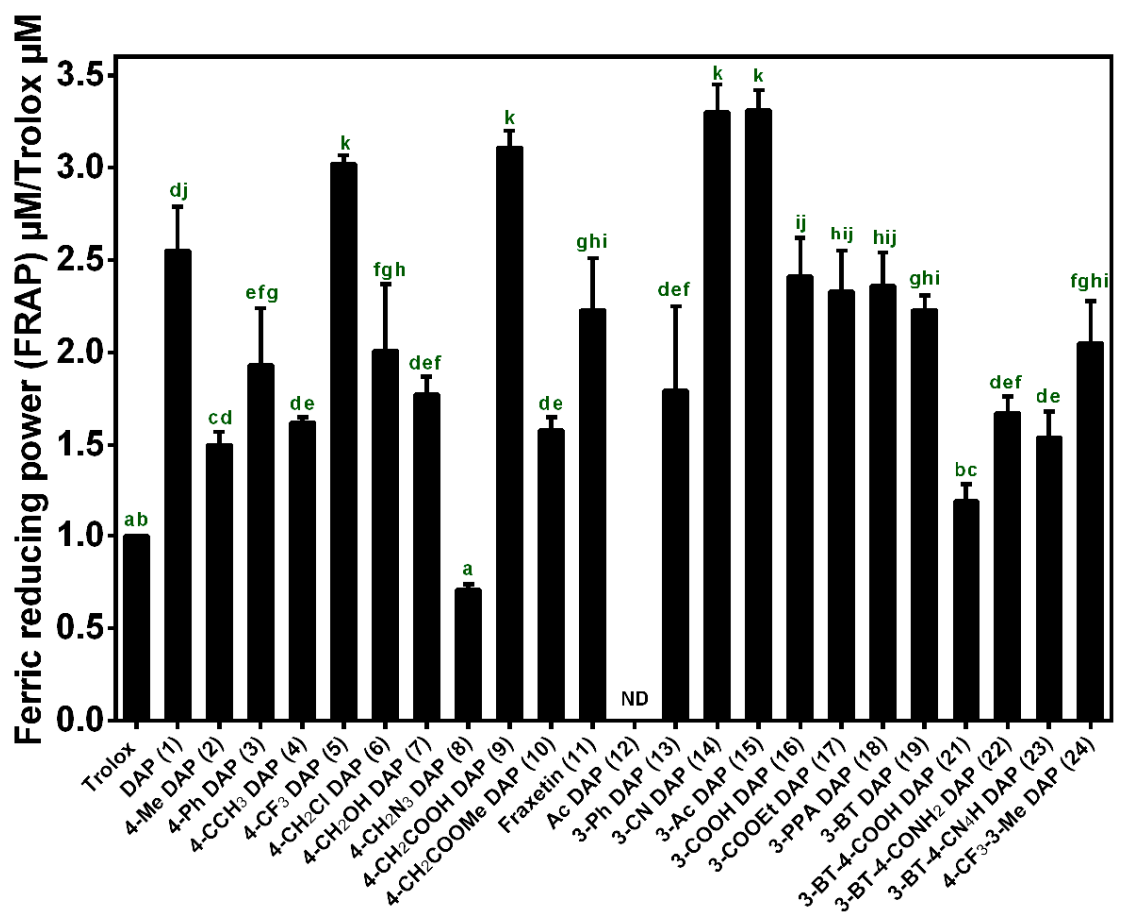

Figure 2. Ferric reducing power of daphnetin and its derivatives. Values marked by the same alphabet are not significantly different $(p<0.05)$.

Table 1. Antioxidant activity of daphnetin derivatives tested in 2,2'-diphenyl-1-picrylhydrazyl (DPPH) and 2,2'-azinobis-(3-ethylbenzthiazoline-6-sulfonate) cation $\left(\mathrm{ABTS}^{+}\right)$assays.DAP $=$daphnetin.

\begin{tabular}{|c|c|c|}
\hline Compound & $\mathrm{DPPH}\left(\mathrm{EC}_{50} / \mu \mathrm{M}\right)$ & $\mathrm{ABTS}^{+}\left(\mathrm{EC}_{50} / \mu \mathrm{M}\right)$ \\
\hline Trolox & $53.16 \pm 2.02 \mathrm{ab}$ & $241.33 \pm 2.52^{\mathrm{k}}$ \\
\hline DAP (1) & $46.20 \pm 1.45^{a b}$ & $159.34 \pm 4.63$ fghi \\
\hline 4-Me DAP (2) & $85.63 \pm 2.13^{c}$ & $224.50 \pm 1.94^{\mathrm{ijk}}$ \\
\hline 4-Ph DAP (3) & $55.60 \pm 0.78^{a b}$ & $198.33 \pm 28.18^{\mathrm{ijk}}$ \\
\hline $4-\mathrm{CCH}_{3}$ DAP (4) & $65.50 \pm 2.84^{b c}$ & $234.68 \pm 2.03^{k}$ \\
\hline $4-\mathrm{CF}_{3} \mathrm{DAP}(5)$ & $45.69 \pm 1.26^{\mathrm{ab}}$ & $75.23 \pm 1.58^{\mathrm{ab}}$ \\
\hline 4- $\mathrm{CH}_{2} \mathrm{Cl} \mathrm{DAP}(6)$ & $46.57 \pm 2.57 \mathrm{ab}$ & $107.39 \pm 6.72$ abcde \\
\hline 4- $\mathrm{CH}_{2} \mathrm{OH}$ DAP (7) & $61.99 \pm 1.43^{b c}$ & $184.94 \pm 2.04^{\text {hij }}$ \\
\hline $4-\mathrm{CH}_{2} \mathrm{~N}_{3} \mathrm{DAP}(8)$ & $62.17 \pm 3.73 \mathrm{bc}$ & $238.31 \pm 4.47^{\mathrm{k}}$ \\
\hline 4- $\mathrm{CH}_{2} \mathrm{COOH}$ DAP (9) & $31.38 \pm 0.68^{a}$ & $72.31 \pm 2.70^{\mathrm{a}}$ \\
\hline 4- $\mathrm{CH}_{2} \mathrm{COOMe}$ DAP (10) & $50.20 \pm 1.12^{a b}$ & $222.70 \pm 1.84^{\mathrm{jk}}$ \\
\hline Fraxetin (11) & $45.59 \pm 1.48^{\mathrm{ab}}$ & $173.07 \pm 4.83$ ghi \\
\hline Ac DAP (12) & $698.04 \pm 5.22^{f}$ & $4562.49 \pm 50.1^{1}$ \\
\hline 3-Ph DAP (13) & $43.67 \pm 2.08^{a b}$ & $108.01 \pm 1.42^{\text {abcde }}$ \\
\hline 3-CN DAP (14) & $47.02 \pm 2.05^{\mathrm{ab}}$ & $95.80 \pm 4.18^{\mathrm{abcd}}$ \\
\hline 3-Ac DAP (15) & $50.62 \pm 0.61^{\mathrm{ab}}$ & $80.52 \pm 0.61 \mathrm{abc}$ \\
\hline 3-COOH DAP (16) & $37.67 \pm 1.16^{\mathrm{ab}}$ & $145.67 \pm 5.77$ efgh \\
\hline 3-COOEt DAP (17) & $43.98 \pm 0.89 \mathrm{ab}$ & $138.88 \pm 0.14^{\text {defg }}$ \\
\hline 3-PPA DAP (18) & $55.65 \pm 1.48^{a b}$ & $91.25 \pm 2.29 \mathrm{abcd}$ \\
\hline 3-BT DAP (19) & $71.31 \pm 2.40^{b c}$ & $86.57 \pm 3.17^{\mathrm{abcd}}$ \\
\hline 3-BT-4-COOH DAP (21) & $130.50 \pm 3.54^{d}$ & $108.33 \pm 6.35^{\text {abcde }}$ \\
\hline 3-BT-4-CONH${ }_{2}$ DAP (22) & $66.82 \pm 1.38^{b c}$ & $122.34 \pm 4.41$ bcdef \\
\hline 3-BT-4-CN 4 H DAP (23) & $167.85 \pm 11.63^{\mathrm{e}}$ & $121.72 \pm 0.22^{\mathrm{cdef}}$ \\
\hline 4-CF $3-3-\mathrm{Me}$ DAP (24) & $53.76 \pm 2.25^{\mathrm{ab}}$ & $107.21 \pm 6.23^{\text {abcde }}$ \\
\hline
\end{tabular}


In the $\mathrm{ABTS}^{+}$radical assay, Table 1 and Figure 3 indicated that 4-carboxymethyl DAP 9 also showed strong scavenging activity on the $\mathrm{ABTS}^{+}$radical, and their $\mathrm{EC}_{50}$ values were $72.38 \mu \mathrm{M}$. Similar to the FRAP assay and DPPH assay results, the $\mathrm{ABTS}^{+}$radical scavenging ability of the daphnetins could be significantly enhanced by the substitution of a strong electron-withdrawing carboxyl group on the C-4 position. Taken together, 4-carboxymethyl DAP 9 is the most powerful antioxidant in these compounds and led to the best antioxidant activity observed in all the assays used in this study. In addition, diacetyl DAP 12 displayed very low antioxidative capacity with an $\mathrm{EC}_{50}$ value of $4562.49 \mu \mathrm{M}$. This provides additional evidence for the importance of the presence of two hydroxylated groups at the ortho position for the antioxidant activity of these compounds.
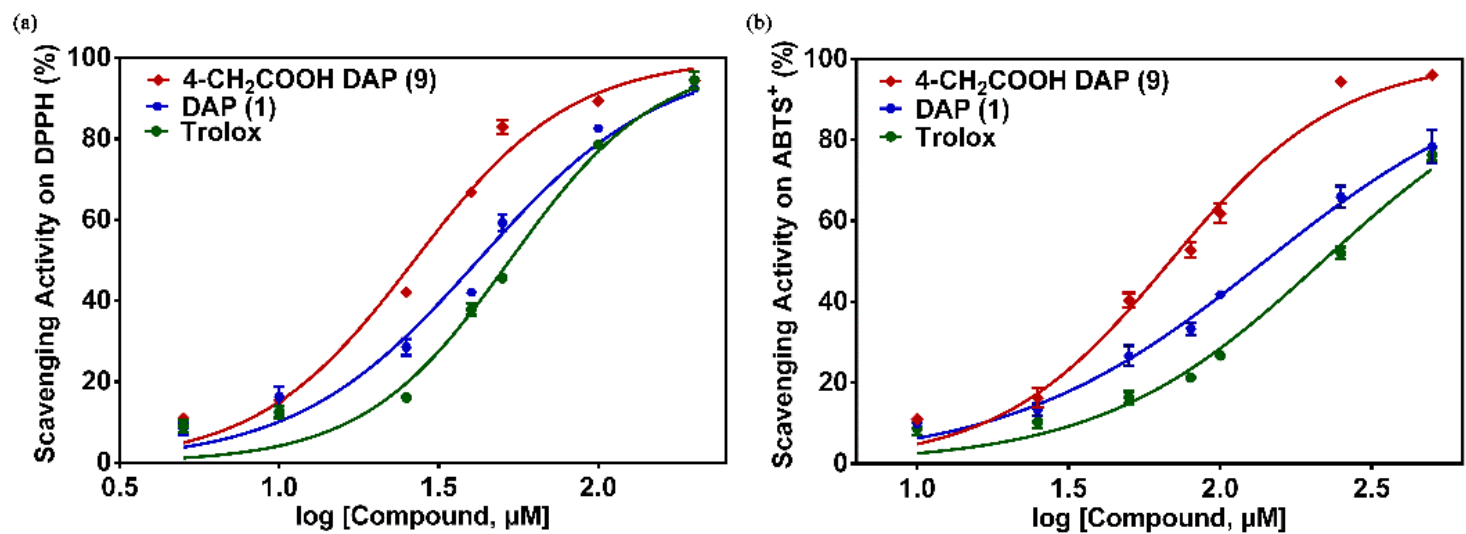

Figure 3. Concentration-response curve for the radical-scavenging activity of 4- $\mathrm{CH}_{2} \mathrm{COOH} \mathrm{DAP}(9)$, daphnetin (DAP) (1), and positive control compound Trolox in 2,2'-diphenyl-1-picrylhydrazyl (DPPH) (a) and 2,2'-azinobis-(3-ethylbenzthiazoline-6-sulfonate) cation $\left(\mathrm{ABTS}^{+}\right)(\mathbf{b})$ assays.

Based on these observations, a brief structure-activity relationship could be summarized. The existence of the phenolic groups and their positions are very important for the antioxidant activity of daphnetin. In particular, the catechol moiety plays a key role in enhancing the radical scavenging and ferric reducing activities. The introduction of an electron withdrawing hydrophilic group, such as a carboxyl group at the C-4 position of daphnetin, could enhance the antioxidative capacity significantly, but this trend was not observed in the C-3 substitution. However, the introduction of a hydrophobic phenyl group exhibited negative effects on the antioxidant activity in both the C-3 and C-4 substitutions. It is worth repeating that the carboxyl group displays more positive effects than all the other substituents, implying that the carboxyl group could serve as a pharmacophore for the antioxidant activity of daphnetins, and experiments to examine the antioxidant mechanism of carboxymethyl-substituted daphnetins are merited.

Although catechol coumarins have been reported to possess a variety of therapeutic benefits, this family suffers from low oral bioavailability due to poor metabolic stability [25,26]. The simultaneous improvement of utility as a drug and pharmacological activity is still a challenge for the structural optimization of lead compounds. From the view of the chemical structure, the catechol group is not only the pharmacophore of the coumarins but also the susceptible group for the attack of phase II metabolic enzymes. As phenolic hydroxyls, catechol coumarins primarily undergo conjugative reactions mediated by phase II metabolizing enzymes, including uridine-5-diphosphate glucuronosyl transferase (UGT) and catechol-O-methyltransferase (COMT) [27-29]. Considering that compound 9 exhibited the best antioxidant result in this study, the metabolic elimination $t_{1 / 2}$ of compound 9 in the UGT and COMT incubation systems was investigated in more detail and compared with that of Compound 1 in vitro (Supporting Information). The results demonstrated a five-fold longer $t_{1 / 2}$ for compound 9 than that of compound 1, with $t_{1 / 2}$ values of $96.5 \mathrm{~min}$ and $20.3 \mathrm{~min}$, respectively (Figure S1). These results indicated that C-4 carboxyethyl substitution improves the metabolic 
stability of daphnetin. In summary, 4-carbethoxyl DAP 9 holds strong potential to be developed as an antioxidant agent with excellent antioxidant activity and good pharmacokinetic properties.

\section{Materials and Methods}

\subsection{Materials and Measurements}

The ${ }^{1} \mathrm{H}$ NMR and ${ }^{13} \mathrm{C}$ NMR spectra were recorded on a Bruker ARX (Bruker, Rheinstetten, Germany) $400 \mathrm{MHz}$ or Bruker AMX $400 \mathrm{MHz}$ or $600 \mathrm{MHz}$ spectrometer in dimethyl sulfoxide (DMSO- $d_{6}$ ) if not noted otherwise, and the chemical shifts were expressed as ppm using trimethylsilane (TMS) as an internal reference. High-resolution mass spectral (HRMS) analyses were measured on a TripleTOFTM Mass Spectrometer (TripleTOF 5600, SCIEX, Foster City, CA, USA). Daphnetin and its derivatives were analyzed using an ultra-fast liquid chromatography spectrometry system (Shimadzu, Kyoto, Japan) equipped with two LC-20AD pumps, a DGU-20A3 vacuum degasser, a SIL-20ACHT auto-sampler, a CTO-20AC column oven, and an SPD-M 20A diode-array detector (DAD). All the reagents used in the synthesis were obtained commercially and used without further purification. The reactions were monitored using thin layer chromatography (TLC) on glass packed precoated silica gel $\mathrm{GF}_{254}$ plates. Flash column chromatography was performed using silica gel (200-300 mesh), which was purchased from the Qingdao Ocean Chemical Co., Ltd (Qingdao, China). Daphnetin and 11 were purchased from Chengdu Pufei De Biotech Co., Ltd. (Sichuan, China).

\subsection{Synthesis of 4-Substituted Daphnetin Derivatives}

General procedure for the synthesis of 4-substituted daphnetin derivatives (2-6): Perchloric acid (5.0 mL) was added drop-wise at room temperature to a mixture of 1,2,3-phenenyl triacetate $(5.0 \mathrm{mmol})$ and the correctly substituted $\beta$-ketoester $(10.0 \mathrm{mmol})$ and stirred for $6-8 \mathrm{~h}$. After TLC analysis indicated that the reaction was complete, the reaction mixture was slowly poured into a mixture of ice water $(100 \mathrm{~mL})$ with stirring. The resultant suspension was filtered, and the collected solid was washed with water and dried; the crude compound was recrystallized from methanol to produce the desired compound [30].

7,8-Dihydroxy-4-methyl-2H-chromen-2-one (2): Using the general procedure, 1,2,3-phenenyl triacetate was combined with ethyl acetoacetate in the presence of perchloric acid and left to react. The crude compound was recrystallized from the methanol to produce compound 2 as a light white solid with a yield of $78 \%$. ${ }^{1} \mathrm{H}$ NMR $(600 \mathrm{MHz}, \mathrm{DMSO}) \delta 10.05(\mathrm{~s}, 1 \mathrm{H}), 9.28(\mathrm{~s}, 1 \mathrm{H}), 7.09(\mathrm{~d}, J=8.6 \mathrm{~Hz}, 1 \mathrm{H})$, $6.82(\mathrm{~d}, J=8.6 \mathrm{~Hz}, 1 \mathrm{H}), 6.13(\mathrm{~d}, J=1.1 \mathrm{~Hz}, 1 \mathrm{H}), 2.36(\mathrm{~s}, 3 \mathrm{H}) ;{ }^{13} \mathrm{C}$ NMR $(151 \mathrm{MHz}, \mathrm{DMSO}) \delta 160.67$, $154.40,149.87,143.79,132.62,115.95,113.23,112.58,110.65,18.72$; HRMS (ESI) for $\mathrm{C}_{10} \mathrm{H}_{8} \mathrm{O}_{4}$, Calcd. 192.0423, found $192.0355[\mathrm{M}-\mathrm{H}]^{-}$.

7,8-Dihydroxy-4-phenyl-2H-chromen-2-one (3): Using the general procedure, 1,2,3-phenenyl triacetate was combined with ethyl benzoylacetate in the presence of perchloric acid and left to react. The crude compound was recrystallized from the methanol to produce compound 3 as a white solid with a yield of $82 \% .{ }^{1} \mathrm{H}$ NMR $(600 \mathrm{MHz}, \mathrm{DMSO}) \delta 10.19(\mathrm{~s}, 1 \mathrm{H}), 9.42(\mathrm{~s}, 1 \mathrm{H}), 7.77-7.32(\mathrm{~m}, 5 \mathrm{H}), 6.88-6.65(\mathrm{~m}, 2 \mathrm{H})$, $6.14(\mathrm{~s}, 1 \mathrm{H}) ;{ }^{13} \mathrm{C}$ NMR $(151 \mathrm{MHz}, \mathrm{DMSO}) \delta$ 160.56, 156.42, 150.11, 144.37, 135.94, 133.10, 129.94, 129.20, 128.90, 117.78, 112.81, 111.97, 110.72; HRMS (ESI) for $\mathrm{C}_{15} \mathrm{H}_{10} \mathrm{O}_{4}$, Calcd. 254.0579, found 253.0515 $[\mathrm{M}-\mathrm{H}]^{-}$.

7,8-Dihydroxy-4-tert-butyl-2H-chromen-2-one (4): Using the general procedure, 1,2,3-phenenyl triacetate was combined with ethyl 4,4-dimethyl-3-oxovalerate in the presence of perchloric acid and left to react. The crude compound was recrystallized from methanol and purified using flash column chromatography on silica gel to produce compound 4 as a white solid with a yield of $39 \% .{ }^{1} \mathrm{H} \mathrm{NMR}$ $(600 \mathrm{MHz}, \mathrm{DMSO}) \delta 10.21(\mathrm{~s}, 1 \mathrm{H}), 9.25(\mathrm{~s}, 1 \mathrm{H}), 7.34(\mathrm{~d}, J=8.6 \mathrm{~Hz}, 1 \mathrm{H}), 6.91(\mathrm{~d}, J=8.7 \mathrm{~Hz}, 1 \mathrm{H}), 6.04(\mathrm{~s}, 1 \mathrm{H})$, 1.33 (s, 9H); ${ }^{13} \mathrm{C}$ NMR (151 MHz, DMSO) $\delta 177.58,175.25,150.54,147.23,133.35,116.88,115.31,114.13$, 105.45, 36.69, 28.04. HRMS (ESI) for $\mathrm{C}_{13} \mathrm{H}_{14} \mathrm{O}_{4}$, Calcd. 234.0892, found $233.0826[\mathrm{M}-\mathrm{H}]^{-}$. 
7,8-Dihydroxy-4-trifluoromethyl-2H-chromen-2-one (5): Using the general procedure, 1,2,3-phenenyl triacetate was combined with ethyl 4,4,4-trifluoroacetoacetate in the presence of perchloric acid and left to react. The crude compound was recrystallized from methanol to produce compound 5 as a yellow solid with a yield of 58\%. ${ }^{1} \mathrm{H}$ NMR $(600 \mathrm{MHz}, \mathrm{DMSO}) \delta 10.53(\mathrm{~s}, 1 \mathrm{H}), 9.61(\mathrm{~s}, 1 \mathrm{H}), 7.07(\mathrm{dd}, J=8.8$, $1.8 \mathrm{~Hz}, 1 \mathrm{H}), 6.92(\mathrm{~d}, J=8.8 \mathrm{~Hz}, 1 \mathrm{H}), 6.74(\mathrm{~s}, 1 \mathrm{H}) ;{ }^{13} \mathrm{C} \mathrm{NMR}(151 \mathrm{MHz}, \mathrm{DMSO}) \delta 159.29,151.03,144.54$, 140.76, 140.55, 133.40, 115.73, 113.61, 112.27, 106.45; HRMS (ESI) for $\mathrm{C}_{10} \mathrm{H}_{5} \mathrm{~F}_{3} \mathrm{O}_{4}$, Calcd. 236.0140, found $245.0072[\mathrm{M}-\mathrm{H}]^{-}$.

7,8-Dihydroxy-4-chloromethyl-2H-chromen-2-one (6): Using the general procedure, 1,2,3-phenenyl triacetate was combined with ethyl 4-chloroacetoacetate in the presence of perchloric acid and left to react. The crude compound was recrystallized from methanol to produce compound $\mathbf{6}$ as a white solid with a yield of $69 \% .{ }^{1} \mathrm{H}$ NMR $(600 \mathrm{MHz}, \mathrm{DMSO}) \delta 10.19(\mathrm{~s}, 1 \mathrm{H}), 9.40(\mathrm{~s}, 1 \mathrm{H}), 7.18(\mathrm{~d}, J=8.7 \mathrm{~Hz}, 1 \mathrm{H})$, $6.85(\mathrm{~d}, J=8.7 \mathrm{~Hz}, 1 \mathrm{H}), 6.42(\mathrm{~s}, 1 \mathrm{H}), 4.94(\mathrm{~s}, 2 \mathrm{H}) ;{ }^{13} \mathrm{C}$ NMR $(151 \mathrm{MHz}, \mathrm{DMSO}) \delta 160.55,151.86,150.23$, 144.15, 132.92, 115.95, 112.79, 111.42, 110.57, 41.95; HRMS (ESI) for $\mathrm{C}_{10} \mathrm{H}_{7} \mathrm{ClO}_{4}$, Calcd. 226.0033, found $224.9967[\mathrm{M}-\mathrm{H}]^{-}$.

7,8-Dihydroxy-4-hydroxymethyl-2H-chromen-2-one (7): Chloride 6 (0.5 g, $2.2 \mathrm{mmol})$ was dissolved in a mixture of DMF $(3 \mathrm{~mL})$ and $\mathrm{H}_{2} \mathrm{O}(10 \mathrm{~mL})$ with stirring and refluxed for $20 \mathrm{~h}$. After TLC indicated that the reaction was complete, the mixture was diluted with water. The resultant suspension was filtered, and the collected solid was washed with water and dried. The crude compound was recrystallized from methanol to yield hydroxymethyl 7 as a light brown solid with a yield of $80 \% .{ }^{1} \mathrm{H} \mathrm{NMR}(600 \mathrm{MHz}$, DMSO) $\delta 10.03(\mathrm{~s}, 1 \mathrm{H}), 9.30(\mathrm{~s}, 1 \mathrm{H}), 7.01(\mathrm{~d}, J=8.7 \mathrm{~Hz}, 1 \mathrm{H}), 6.78(\mathrm{~d}, J=8.6 \mathrm{~Hz}, 1 \mathrm{H}), 6.24(\mathrm{t}, J=1.4$ $\mathrm{Hz}, 1 \mathrm{H}), 5.55(\mathrm{t}, J=5.5 \mathrm{~Hz}, 1 \mathrm{H}), 4.69(\mathrm{~d}, J=4.2 \mathrm{~Hz}, 2 \mathrm{H}) ;{ }^{13} \mathrm{C}$ NMR (151 MHz, DMSO) $\delta 161.03,157.70$, 149.75, 143.82, 132.75, 114.75, 112.65, 110.73, 106.85, 59.56; HRMS (ESI) for $\mathrm{C}_{10} \mathrm{H}_{8} \mathrm{O}_{5}$, Calcd. 208.0372, found $207.0304[\mathrm{M}-\mathrm{H}]^{-}$.

7,8-Dihydroxy-4-azidemethyl-2H-chromen-2-one (8): Chloride 6 (0.5 g, $2.2 \mathrm{mmol})$ was dissolved in DMF $(10 \mathrm{~mL})$ and sodium azide $(0.37 \mathrm{~g}, 5.5 \mathrm{mmol})$ was added and stirred overnight. After LC-MS indicated that the reaction was complete, the mixture was diluted with water. The resultant suspension was filtered, and the collected solid was washed with water and dried. The crude compound was recrystallized from methanol to yield azidemethyl 8 as a grey solid with a yield of $85 \% .{ }^{1} \mathrm{H}$ NMR $(600 \mathrm{MHz}, \mathrm{DMSO}) \delta 10.18(\mathrm{~s}, 1 \mathrm{H}), 9.41(\mathrm{~s}, 1 \mathrm{H}), 7.06(\mathrm{~d}, J=8.7 \mathrm{~Hz}, 1 \mathrm{H}), 6.83(\mathrm{~d}, J=8.7 \mathrm{~Hz}, 1 \mathrm{H})$, $6.27(\mathrm{~s}, 1 \mathrm{H}), 4.77(\mathrm{~d}, J=0.8 \mathrm{~Hz}, 2 \mathrm{H}) ;{ }^{13} \mathrm{C}$ NMR $(151 \mathrm{MHz}, \mathrm{DMSO}) \delta 160.47,151.05,150.26,144.01,132.88$, 115.51, 112.82, 110.74, 109.76, 50.19; HRMS (ESI) for $\mathrm{C}_{10} \mathrm{H}_{7} \mathrm{~N}_{3} \mathrm{O}_{4}$, Calcd. 233.0437, found 234.0513 $[\mathrm{M}+\mathrm{H}]^{+}$.

2-(7,8-Dihydroxy-2-oxo-2H-chromen-4-yl)acetic acid (9): Using the general procedure, 1,2,3-phenenyl triacetate was combined with 1,3-acetonedicarboxylic acid in the presence of perchloric acid and left to react. The crude compound was recrystallized from methanol to yield compound $\mathbf{9}$ as a white solid with a yield of 78\%. ${ }^{1} \mathrm{H}$ NMR (400 MHz, DMSO) $\delta 12.75(\mathrm{~s}, 1 \mathrm{H}), 10.11(\mathrm{~s}, 1 \mathrm{H}), 9.35(\mathrm{~s}, 1 \mathrm{H}), 7.03$ $(\mathrm{d}, J=8.7 \mathrm{~Hz}, 1 \mathrm{H}), 6.81(\mathrm{~d}, J=8.7 \mathrm{~Hz}, 1 \mathrm{H}), 6.22(\mathrm{~s}, 1 \mathrm{H}), 3.80(\mathrm{~s}, 2 \mathrm{H}) ;{ }^{13} \mathrm{C}$ NMR $(100 \mathrm{MHz}, \mathrm{DMSO}) \delta$ $171.23,160.63,150.99,149.93,143.95,132.74,116.03,112.71,112.57,112.43,37.88$.

Methyl 2-(7,8-dihydroxy-2-oxo-2H-chromen-4-yl)acetic acid (10). Using the general procedure, 1,2,3-phenenyl triacetate was combined with dimethyl 1,3-acetonedicarboxylate in the presence of perchloric acid and left to react. The crude compound was recrystallized from methanol to yield compound 10 as a white solid with a yield of $83 \% .{ }^{1} \mathrm{H}$ NMR $(600 \mathrm{MHz}, \mathrm{DMSO}) \delta 10.12(\mathrm{~s}, 1 \mathrm{H}), 9.36$ $(\mathrm{s}, 1 \mathrm{H}), 7.01(\mathrm{~d}, J=8.7 \mathrm{~Hz}, 1 \mathrm{H}), 6.81(\mathrm{~d}, J=8.7 \mathrm{~Hz}, 1 \mathrm{H}), 6.24(\mathrm{~s}, 1 \mathrm{H}), 3.92(\mathrm{~s}, 2 \mathrm{H}), 3.65(\mathrm{~s}, 3 \mathrm{H}) ;{ }^{13} \mathrm{C} \mathrm{NMR}$ (151 MHz, DMSO) $\delta 170.20,160.52,150.33,150.06,143.96,132.78,116.00,112.77,112.57,112.40,52.64$, 37.27. HRMS (ESI) for $\mathrm{C}_{16} \mathrm{H}_{10} \mathrm{O}_{6}$, Calcd. 250.0477, found $249.0413[\mathrm{M}-\mathrm{H}]^{-}$.

2-oxo-2H-Chromene-7,8-diyl diacetate (12): A solution of daphnetin 1 (0.5 g, $2.8 \mathrm{mmol})$, pyridine $(2.0 \mathrm{~mL})$ and acetic anhydride $(1 \mathrm{~mL})$ in dichloromethane $(\mathrm{DCM})(30 \mathrm{~mL})$ was stirred overnight. After TLC indicated that the reaction was complete, the reaction mixture was poured into water and 
acidified with $1 \mathrm{~mol} / \mathrm{L}$ hydrochloric acid. The reaction mixture was extracted with DCM $(50 \mathrm{~mL} \times 3)$. The combined organic layer was washed with water and brine, dried over anhydrous sodium sulfate, and concentrated by evaporation. The resultant suspension was recrystallized from methanol to yield ester 12 as a grey solid with a yield of $92 \% .{ }^{1} \mathrm{H} \mathrm{NMR}\left(400 \mathrm{MHz}, \mathrm{CDCl}_{3}\right) \delta 10.22(\mathrm{~s}, 1 \mathrm{H}), 8.40(\mathrm{~s}, 1 \mathrm{H})$, $7.59(\mathrm{~d}, J=8.6 \mathrm{~Hz}, 1 \mathrm{H}), 7.42-7.10(\mathrm{~m}, 1 \mathrm{H}), 2.43(\mathrm{~s}, 3 \mathrm{H}), 2.36(\mathrm{~s}, 3 \mathrm{H}) ;{ }^{13} \mathrm{C} \mathrm{NMR}\left(101 \mathrm{MHz}, \mathrm{CDCl}_{3}\right) \delta$ 187.26, 167.34, 167.06, 158.66, 148.72, 148.01, 144.99, 130.57, 127.95, 121.23, 120.13, 116.85, 20.69, 20.27.

\subsection{Synthesis of 3-Substituted Daphnetin Derivatives}

The synthetic routes of daphnetin derivatives 13-19 are illustrated in Scheme 2, and the details in the synthetic procedure of the compounds are described in the Supporting Information based on our previous study [18].

3-(Benzo[d]thiazol-2-yl)-7,8-dihydroxy-2-oxo-2H-chromene-4-carboxylic acid (21) and 3-(benzo[d]thiazol-2-yl) -7,8-dihydroxy-2-oxo-2H-chromene-4-carboxamide (22): $\mathrm{NaCN}(0.24 \mathrm{~g}, 5.4 \mathrm{mmol})$ was added to a solution of $19(0.5 \mathrm{~g}, 1.6 \mathrm{mmol})$ in DMF $(10 \mathrm{~mL})$ and stirred for $3 \mathrm{~h}$ at $50{ }^{\circ} \mathrm{C}$. After the reaction was cooled to $0{ }^{\circ} \mathrm{C}, \mathrm{I}_{2}(0.60 \mathrm{~g}, 2.4 \mathrm{mmol})$ was added and stirred for $5 \mathrm{~h}$. After TLC indicated that the reaction was complete, the reaction mixture was poured into water and treated with an aqueous solution of $\mathrm{NaHSO}_{3}$. The reaction mixture was extracted with ethyl acetate. The combined organic layer was washed with water and brine, dried over anhydrous sodium sulfate, and concentrated by evaporation. The resultant suspension was recrystallized from methanol to yield compound 20 as a brown solid. Compound 20 was suspended in $60 \%$ sulfuric acid solution and heated to $100{ }^{\circ} \mathrm{C}$ for $8 \mathrm{~h}$. The reaction mixture was extracted with abundant ethyl acetate and methanol. The combined organic layer was concentrated by evaporation and purified using preparative high-performance liquid chromatography to yield acid 21 with a yellowish-brown solid with a yield of $60 \%$. ${ }^{1} \mathrm{H}$ NMR (600 MHz, DMSO) $\delta 14.30$ $(\mathrm{s}, 1 \mathrm{H}), 10.84(\mathrm{~s}, 1 \mathrm{H}), 9.77(\mathrm{~s}, 1 \mathrm{H}), 8.18(\mathrm{~d}, J=7.8 \mathrm{~Hz}, 1 \mathrm{H}), 7.97(\mathrm{~d}, J=8.1 \mathrm{~Hz}, 1 \mathrm{H}), 7.61-7.53(\mathrm{~m}, 1 \mathrm{H})$, $7.52-7.46(\mathrm{~m}, 1 \mathrm{H}), 7.05(\mathrm{~d}, J=8.7 \mathrm{~Hz}, 1 \mathrm{H}), 7.00(\mathrm{~d}, J=8.7 \mathrm{~Hz}, 1 \mathrm{H}) ;{ }^{13} \mathrm{C}$ NMR $(151 \mathrm{MHz}, \mathrm{DMSO}) \delta 166.56$, $160.36,159.17,152.45,152.13,143.79,136.00,132.90,126.97,125.92,123.02,122.48,119.02,114.52,109.64$; HRMS (ESI) for $\mathrm{C}_{17} \mathrm{H}_{9} \mathrm{NO}_{6} \mathrm{~S}$, Calcd. 355.0151, found 354.0084 [M - H] $]^{-}$.

Compound 20 was suspended in $60 \%$ sulfuric acid solution and heated to $80{ }^{\circ} \mathrm{C}$ for $3 \mathrm{~h}$. The reaction mixture was extracted with abundant ethyl acetate and methanol. The combined organic layer was concentrated by evaporation and purified using preparative high-performance liquid chromatography to yield acid 22 with a yellowish-brown solid with a yield of $36 \%$. ${ }^{1} \mathrm{H}$ NMR (600 MHz, DMSO) $\delta 10.77(\mathrm{~s}, 1 \mathrm{H}), 9.67(\mathrm{~s}, 1 \mathrm{H}), 8.16(\mathrm{~d}, J=7.6 \mathrm{~Hz}, 1 \mathrm{H}), 8.06(\mathrm{~s}, 1 \mathrm{H}), 8.00-7.90(\mathrm{~m}, 2 \mathrm{H})$, 7.60-7.53 (m, 1H), 7.52-7.45 (m, 1H), $7.14(\mathrm{~d}, J=8.8 \mathrm{~Hz}, 1 \mathrm{H}), 6.99(\mathrm{~d}, J=8.8 \mathrm{~Hz}, 1 \mathrm{H}) ;{ }^{13} \mathrm{C} \mathrm{NMR}(151 \mathrm{MHz}$, DMSO) $\delta 166.50,160.63,159.42,152.39,152.09,151.09,143.76,135.97,132.67,126.75,125.81,123.14$, 122.31, 119.61, 114.28, 110.49, 109.76; HRMS (ESI) for $\mathrm{C}_{17} \mathrm{H}_{9} \mathrm{~N}_{2} \mathrm{O}_{5} \mathrm{~S}$, Calcd. 354.0310, found 353.0245 $[\mathrm{M}-\cdot \mathrm{H}]^{-}$.

3-(Benzo[d]thiazol-2-yl)-7,8-dihydroxy-4-(1H-tetrazol-5-yl)-2H-chromen-2-one (23): $\mathrm{NaN}_{3}$ (0.30 g $\left.4.5 \mathrm{mmol}\right)$ was added to a solution of $19(0.25 \mathrm{~g}, 0.8 \mathrm{mmol})$ and $\mathrm{ZnBr}_{2}(0.45 \mathrm{~g}, 2.0 \mathrm{mmol})$ in dioxan $(20 \mathrm{~mL})$ and heated to $90{ }^{\circ} \mathrm{C}$ for $10 \mathrm{~h}$. After TLC indicated that the reaction was complete, the reaction mixture was extracted with abundant ethyl acetate and methanol. The combined organic layer was concentrated by evaporation and purified using preparative high-performance liquid chromatography to yield acid 23 with a brown solid with a yield of 42\%. ${ }^{1} \mathrm{H}$ NMR (600 MHz, DMSO) $\delta 10.88(\mathrm{~s}, 1 \mathrm{H}), 9.84(\mathrm{~s}, 1 \mathrm{H})$, 8.16-8.08 (m, 1H), $7.53(\mathrm{~d}, J=7.4 \mathrm{~Hz}, 1 \mathrm{H}), 7.48-7.36(\mathrm{~m}, 2 \mathrm{H}), 6.90(\mathrm{~d}, J=8.8 \mathrm{~Hz}, 1 \mathrm{H}), 6.50(\mathrm{~d}, J=8.7 \mathrm{~Hz}$, $1 \mathrm{H}) ;{ }^{13} \mathrm{C}$ NMR $(151 \mathrm{MHz}, \mathrm{DMSO}) \delta 159.54,152.62,151.88,143.19,135.88,132.96,126.89,126.14,123.07$, 122.32, 119.23, 115.91, 114.29, 112.24, HRMS (ESI) for $\mathrm{C}_{17} \mathrm{H}_{9} \mathrm{~N}_{5} \mathrm{O}_{4} \mathrm{~S}$, Calcd. 379.0375, found 378.0311 $[\mathrm{M}-\mathrm{H}]^{-}$.

7,8-Dihydroxy-3-methyl-4-(trifluoromethyl)-2H-chromen-2-one (24): Drop-wise perchloric acid (5.0 mL) was added to a mixture of 1,2,3-phenenyl triacetate $(0.5 \mathrm{~g}, 2.0 \mathrm{mmol})$ and ethyl 4,4,4-trifluoro2-methyl-3-oxobutanoate $(0.4 \mathrm{~g}, 0.2 \mathrm{mmol})$ at room temperature and stirred for $6 \mathrm{~h}$. After TLC indicated 
that the reaction was complete, the reaction mixture was poured into water and extracted with ethyl acetate. The combined organic layer was washed with water and brine, dried over anhydrous sodium sulfate, and concentrated by evaporation. The residue was purified by column chromatography using silica gel to obtain compound 24 as a white solid with a yield of $28 \% .{ }^{1} \mathrm{H}$ NMR $(600 \mathrm{MHz}, \mathrm{DMSO}) \delta$ $10.28(\mathrm{~s}, 1 \mathrm{H}), 9.48(\mathrm{~s}, 1 \mathrm{H}), 7.14-6.97(\mathrm{~m}, 1 \mathrm{H}), 6.87(\mathrm{~d}, J=9.0 \mathrm{~Hz}, 1 \mathrm{H}), 2.27(\mathrm{q}, J=3.7 \mathrm{~Hz}, 3 \mathrm{H}) ;{ }^{13} \mathrm{C} \mathrm{NMR}$ (151 MHz, DMSO) $\delta 161.34,149.38,142.52,134.88,134.68,132.87,124.76,123.30,122.91,115.56,113.29$, 107.74, 14.05. HRMS (ESI) for $\mathrm{C}_{11} \mathrm{H}_{7} \mathrm{~F}_{4} \mathrm{O}_{4}$, Calcd. 260.0296, found 259.0231 [M - H] $]^{-}$.

\subsection{Antioxidant Activity Assay In Vitro}

\subsubsection{DPPH Assay}

Each sample in an ethanol solution $(0.1 \mathrm{~mL})$ was added to $3.9 \mathrm{~mL}$ DPPH ethanol solution $(0.1 \mathrm{mmol} / \mathrm{L})$. The solution was vortexed for $10 \mathrm{~s}$ and incubated at room temperature for $30 \mathrm{~min}$. The absorbance of the resulting solution was measured at $517 \mathrm{~nm}$ (Hitachi U-2800 Spectrophotometer, Tokyo, Japan). The Trolox standard solution (concentration range: $0-0.4 \mathrm{mmol} / \mathrm{L}$ ) in ethanol was analyzed under the same conditions as those used for calibration. The values of the DPPH radical scavenging activity were determined using a calibration curve of Trolox and expressed as the Trolox equivalent $\left(\mathrm{TEAC}_{\mathrm{DPPH}}, \mathrm{mmol}\right.$ Trolox/mmol sample).

\subsection{2. $\mathrm{ABTS}^{+}$Assay}

$\mathrm{ABTS}^{+}$solution was produced by reacting $7 \mathrm{mmol} / \mathrm{L}$ ABTS water solution $(10 \mathrm{~mL})$ with $2.45 \mathrm{mmol} / \mathrm{L}$ potassium persulphate $(10 \mathrm{~mL})$. The mixture was incubated in the dark at room temperature for 15-16 h before use. To evaluate the antioxidant activity, the ABTS ${ }^{+}$solution was diluted with ethanol until its absorbance reached 0.7 at $734 \mathrm{~nm}$. Each sample solution $(0.1 \mathrm{~mL}) \mathrm{was}$ added to $3.9 \mathrm{~mL} \mathrm{ABTS}^{+}$solution, and the absorbance was measured at room temperature after $3 \mathrm{~min}$. The Trolox standard solution (concentration range: $0-0.4 \mathrm{mmol} / \mathrm{L}$ ) in ethanol was analyzed under the same conditions as those used for the calibration. Values of the ABTS radical scavenging activity were determined using a calibration curve of Trolox and expressed as the Trolox equivalent (TEAC ABTS, $_{\text {, }}$ mmol Trolox/mmol sample).

\subsubsection{FRAP Assay}

The FRAP (ferric reducing antioxidant power) reagent was prepared with acetate buffer (300 mmol/L, pH 3.6), 2,4,6-tripyridyl-s-triazine (TPTZ) $(10 \mathrm{mmol} / \mathrm{L}$ in $\mathrm{HCl}, 40 \mathrm{mmol} / \mathrm{L})$ and $\mathrm{FeCl}_{3}$ (20 mmol/L). The proportions were 10:1:1 (v:v:v), respectively. Each sample solution was added to the FRAP reagent (1:30, v:v) and incubated at $37{ }^{\circ} \mathrm{C}$ for $5 \mathrm{~min}$. The absorbance was determined at $593 \mathrm{~nm}$ using a spectrophotometer (Hitachi U-2800 Spectrophotometer, Tokyo, Japan). The Trolox standard solution (concentration range: $0-0.4 \mathrm{mmol} / \mathrm{L}$ ) in ethanol was analyzed under the same conditions as those used for the calibration. The values of the reducing power were determined using a calibration curve of Trolox and expressed as the Trolox equivalent (TEAC $\mathrm{FRAP}$, mmolTrolox/mmol sample).

\subsection{Statistical Analysis}

All the experiments were conducted in triplicate, and the data were analyzed using SPSS software (Version 14.0; SPSS, Chicago, IL, USA). A one-way analysis of variance and least significant difference (LSD) were used to differentiate the mean values.

\section{Conclusions}

In summary, daphnetin was chosen as the lead compound and more than twenty derivatives were designed and synthesized by structural modification on C-3 and/or C-4 position of daphnetin. The antioxidant activities of these compounds were assayed. Meanwhile, the potential structure-inhibition relationships of these daphnetin derivatives were well-summarized and discussed. 
The results clearly demonstrated that the catechol group of daphnetins was essential for antioxidant activity, while introduction of an electron withdrawing hydrophilic group at the C-4 position of daphnetin might be beneficial for antioxidant effect. Among all the tested compounds, 4-carboxymethyl daphnetin (compound 9) exhibited the strongest antioxidant activity in all of the assays, implying that this compound could serve as an ideal lead compound for the development of a potent antioxidant. Further investigation on the metabolic stability demonstrated compound 9 exerted a three-fold longer $t_{1 / 2}$ than that of compound 1 in the UGT and COMT incubation systems in vitro. All these findings are very useful for medicinal chemists to design and develop potent antioxidants based on the structural modifications of coumarin derivatives.

Supplementary Materials: The following are available online, Figure S1: Plot of incubation time vs. natural log percent remaining.

Author Contributions: Conceptualization, P.W.; methodology, Y.X., C.C., and T.D.; writing-original draft preparation, Y.X.; writing-review and editing, all authors.

Funding: This work was supported by National Key Research and Development Program of China (2017YFC1700200, 2017YFC1702000), National Natural Science Foundation of China (81603187, 31601517 and 31600641), Natural Science Foundation of Shanghai (18ZR1436500), and the Fundamental Research Funds for the Central Universities (DUT18LK39).

Conflicts of Interest: The authors declare no conflict of interest.

\section{References}

1. Halliwell, B. Free radicals, antioxidants, and human disease: Curiosity, cause, or consequence? Lancet 1994, 344, 721-724. [CrossRef]

2. Niki, E. Free radicals, antioxidants, and cancer. In Food Factors for Cancer Prevention; Ohigashi, H., Osawa, T., Terao, J., Watanabe, S., Yoshikawa, T., Eds.; Springer: Tokyo, Japan, 1997; pp. 55-57.

3. Poulson, H.E.; Prieme, H.; Loft, S. Role of oxidative DNA damage in cancer initiation and promotion. Eur. J. Cancer Prev. 1998, 7, 9-16.

4. Chung, K.T.; Wong, T.Y.; Huang, Y.W.; Lin, Y. Tannins and human health: A review. Crit. Rev. Food Sci. Nutr. 1998, 38, 421-464. [CrossRef] [PubMed]

5. Yang, C.S.; Landau, J.M.; Huang, M.T.; Newmark, H.L. Inhibition of carcinogenesis by dietary polyphenolic compounds. Annu. Rev. Nutr. 2001, 21, 381-406. [CrossRef] [PubMed]

6. Rice-Evans, C.A.; Miller, N.J.; Paganga, G. Structure-antioxidant activity relationships of flavonoids and phenolic acids. Free Radic. Biol. Med. 1996, 20, 933-956. [CrossRef]

7. Nakatani, N. Phenolic antioxidants from herbs and spices. Biofactors 2000, 13, 141-146. [CrossRef] [PubMed]

8. Zheng, W.; Wang, S.Y. Antioxidant activity and phenolic compounds in selected herbs. J. Agric. Food Chem. 2001, 49, 5165-5170. [CrossRef] [PubMed]

9. Borges, F.; Roleira, F.; Milhazes, N.; Santana, L.; Uriarte, E. Simple coumarins and analogues in medicinal chemistry: Occurrence, synthesis and biological activity. Curr. Med. Chem. 2005, 12, 887-916. [CrossRef] [PubMed]

10. Wu, L.; Wang, X.; Xu, W.; Farzaneh, F.; Xu, R. The structure and pharmacological functions of coumarins and their derivatives. Curr. Med. Chem. 2009, 16, 4236-4260. [CrossRef] [PubMed]

11. Riveiro, M.E.; De Kimpe, N.; Moglioni, A.; Vazquez, R.; Monczor, F.; Shayo, C.; Davio, C. Coumarins: Old compounds with novel promising therapeutic perspectives. Curr. Med. Chem. 2010, 17, 1325-1338. [CrossRef] [PubMed]

12. Matos, M.J.; Santana, L.; Uriarte, E.; Delogu, G.; Corda, M.; Fadda, M.B.; Era, B.; Fais, A. New halogenated phenylcoumarins as tyrosinase inhibitors. Bioorg. Med. Chem. Lett. 2011, 21, 3342-3345. [CrossRef] [PubMed]

13. Galkin, A.; Fallarero, A.; Vuorela, P.M. Coumarins permeability in Caco-2 cell model. J. Pharm. Pharmacol. 2009, 61, 177-184. [CrossRef] [PubMed]

14. Gao, Q.; Shan, J.; Di, L.; Jiang, L.; Xu, H. Therapeutic effects of daphnetin on adjuvantinduced arthritic rats. J. Ethnopharmacol. 2008, 120, 259-263. [CrossRef] [PubMed]

15. Zhao, J.; Liu, X.J.; Ma, J.W.; Zheng, R.L. DNA damage in healthy term neonate. Early Hum. Dev. 2004, 77, 89-98. [CrossRef] [PubMed] 
16. Liu, G.A.; Zheng, R.L. Protection against damaged DNA in the single cell by polyphenols. Pharmazie 2002, 57, 852-854. [PubMed]

17. Van der Waterbeemd, H. Quantitative Approaches to Structure Activity Relationships. In the Practice of Medicinal Chemistry; Wermuth, C.G., Ed.; Academic Press: London, UK, 1996; p. 367.

18. Wang, P.; Xia, Y.L.; Zou, L.W.; Qian, X.K.; Dou, T.Y.; Jin, Q.; Li, S.Y.; Yu, Y.; Wang, D.D.; Luo, Q.; et al. An optimized two-photon fluorescent probe for Biological Sensing and Imaging of Catechol-O-methyltransferase. Chemistry 2017, 23, 10800-10807. [CrossRef] [PubMed]

19. Signore, G.; Nifosì, R.; Albertazzi, L.; Storti, B.; Bizzarri, R. Polarity-sensitive coumarins tailored to live cell imaging. J. Am. Chem. Soc. 2010, 132, 1276-1288. [CrossRef] [PubMed]

20. Shahidi, F.; Liyana-Pathirana, C.M.; Wall, D.S. Antioxidant activity of white and black sesame seeds and their hull fractions. Food Chem. 2006, 99, 478-483. [CrossRef]

21. Ozgen, M.; Reese, R.N.; Tulio, J.A.Z.; Scheerens, J.C.; Miller, A.R. Modified 2,2-azino-bis-3-ethylben zothiazoline-6-sulfonic acid (abts) method to measure antioxidant capacity of Selected small fruits and comparison to ferric reducing antioxidant power (FRAP) and 2,2'-diphenyl-1-picrylhydrazyl (DPPH) methods. Food Chem. 2006, 54, 1151-1157. [CrossRef] [PubMed]

22. Benzie, I.F.; Strain, J.J. The ferric reducing ability of plasma (FRAP) as a measure of "antioxidant power": The FRAP assay. Anal. Biochem. 1996, 239, 70-76. [CrossRef] [PubMed]

23. Koleva, I.I.; van Breek, T.A.; Linssen, J.P.H.; Groot, A.D.; Evstatieva, L.N. Screening of plant extracts for antioxidant activity: A comparative study on three testing methods. Phytochem. Anal. 2002, 13, 8-17. [CrossRef] [PubMed]

24. Lu, Y.; Huang, J.; Li, Y.; Ma, T.; Sang, P.; Wang, W.; Gao, C. Variation in nutritional compositions, antioxidant activity and microstructure of Lycopus lucidus Turcz. root at different harvest times. Food Chem. 2015, 183, 91-100. [CrossRef] [PubMed]

25. Qu, S.Y.; Wu, Y.J.; Wang, Y.H.; Zuo, Y.X. Metabolism and pharmacokinetics of daphnetin (article in Chinese). Yao Xие Xие Bao. 1983, 18, 496-500. [PubMed]

26. Tsai, T.H.; Huang, C.T.; Shum, A.Y.; Chen, C.F. Simultaneous blood and biliary sampling of esculetin by microdialysis in the rat. Life Sci. 1999, 65, 1647-1655. [CrossRef]

27. Xia, Y.L.; Liang, S.C.; Zhu, L.L.; Ge, G.B.; He, G.Y.; Ning, J.; Lv, X.; Ma, X.C.; Yang, L.; Yang, S.L. Identification and characterization of human UDP-glucuronosyltransfezzrases responsible for the glucuronidation of fraxetin. Drug Metab. Pharmacokinet. 2014, 29, 135-140. [CrossRef] [PubMed]

28. Liang, S.C.; Xia, Y.L.; Hou, J.; Ge, G.B.; Zhang, J.W.; He, Y.Q.; Wang, J.Y.; Qi, X.Y.; Yang, L. Methylation, glucuronidation, and sulfonation of daphnetin in human hepatic preparations In vitro: Metabolic profiling, pathway comparison, and bioactivity analysis. J. Pharm. Sci. 2016, 105, 808-816. [CrossRef] [PubMed]

29. Xia, Y.L.; Dou, T.Y.; Liu, Y.; Wang, P.; Ge, G.B.; Yang, L. In vitro evaluation of the effect of C-4 substitution on methylation of 7,8-dihydroxycoumarin: Metabolic profile and catalytic kinetics. R. Soc. Open Sci. 2018, 5, 171-271. [CrossRef] [PubMed]

30. Wang, P.; Xia, Y.L.; Yu, Y.; Lu, J.X.; Zou, L.W.; Feng, L.; Ge, G.B.; Yang, L. Design, synthesis and biological evaluation of esculetin derivatives as anti-tumour agents. RSC Adv. 2015, 5, 53477-53483. [CrossRef]

Sample Availability: Samples of the compounds 2-10, 12-24 are available from the authors. 